\title{
From Need Analysis to ELT Study Program Learning Outcome Development: Meeting the Standards of the ASEAN University Network Quality Assurance (AUN-QA)
}

\author{
Refnaldi, Fitrawati, and Aryuliva Adnan \\ English Departmen, ELT Study Program \\ Universitas Negeri Padang \\ refnaldi@yahoo.com
}

\begin{abstract}
Learning outcome, within the context of higher education, is the most important element in the curriculum of a study program because all courses, learning activities, and assessment methods should be alligned with the learning outcomes. This study reports a research on mapping the program learning outcomes of the B.Ed in English Language Education of Universitas Negeri Padang (UNP), Indonesia, as a part of the ongoing research and development to improve the quality of the program, particularly, to meet the standards proposed by the ASEAN University Network Quality Assurance (AUN-QA). The research began with investigating stakeholders' needs on appropriate learning outcomes, and it then continued with the evaluation of the existing study program's learning outcomes and reformulation the learning outcomes based on the AUN-QA criteria. The data in the research were collected through distributing questionnaires to stakeholders, studying existing learning outcomes and relevant documents concerning ELT curriculum of higher education and AUN-QA criteria. The main finding indicates that there are some gaps between the stakeholders' needs and the learning outcomes in the existing curriculum. The reformulation of the learning outcomes was done to fulfill stakesholders' needs and AUN-QA criteria.
\end{abstract}

Keywords: Needs Analysis, AUN-QA, Curriculum Development of ELT Study Program

\section{INTRODUCTION}

One of some roles of universities is as generators of knowledge to prepare students for their contribution to civil society. Darmawati and Parno (2013: 189) say that the concept of intellectual development of educated society is generated from universities. However, many graduates are still unemployed and find it difficult to find work. It becomes a serious challenge for universities in maximizing the potential of human resources. Thus, the university should pay more attention about what needs are essential for now.

As Rino (2012: 2) said that the existence of a university is an asset of a very large nation and has a strategic role in efforts to improve the quality and competitiveness of the nation so it is necessary efforts to further strengthen and maximize the functions and roles for the future. One way to improve the quality of education, to produce qualified graduates, and to have a quality of teaching that meets the standards, universities are supposed to make changes that can be started from the improvement of the curriculum in each study program. The evaluation of the curriculum periodically aims to improve the needs. This is in line with SK Mendiknas no. 232/U/2000 and 045/U/2002 which shows that the government is very serious in improving the quality of education in universities. In addition, the government also emphasized that the applicable curriculum must be in accordance with the vision and mission of the study program. Thus, the role of lecturers is highly demanded in designing, implementing, and evaluating the curriculum in accordance with the demands of the civil society in the future.

Some of the challenges faced in the future should be considered by universities such as globalization (WTO, ASEAN Community, APEC and CAFTA), environmental issues, scientific, and technological progress, knowledge-based economy, the rise of creative and cultural industries, world, influence and impact of techno sciences, quality, inverstation, and transformation in the education sector, and innovation-based and intelligent technology work.

Universitas Negeri Padang is one of several public universities that aims to produce professionals who have moral and religious in the fields of education, science, technology, sports, and art. To realize the vision of Universitas Negeri Padang become one of the best universities in Southeast Asia in the field of science education, science, technology, sports, and art in 2020 , every study program has to prepare the important things to exteriorize the vision. And one of which is the evaluation and development of the curriculum. 
The presence of Asean University Network Quality Assurance (AUN-QA) becomes an opportunity for English Department of Universitas Negeri Padang to realize the vision of the university as one of the leading universities in the ASEAN region. In addition, AUN-QA will also have an impact on the progress and improvement of the quality of education, especially the English Language Teaching department and Universitas Negeri Padang. AUN-QA provides an opportunity for each study program to be able to demonstrate the standards of its education and be eligible to be assessed on ASEAN standards.

There have been several studies that have been conducted related to AUN-QA. Suharmanto, Hidayati, and Zen (2013) had conducted research on how to develop course outlines based on AUN-QA criteria. They says "the department needs to fulfill which were to include the teaching, learning and assessment strategies, quality indicators, and methods for improvement in the program specification, to have curriculum map showing a balance proportion of content, skill, and specialist courses along with their expected learning outcomes, and to conduct didactic methods involving the various methods of assessment". In addition, Hayati, Widiati, Suharmanto, and hidayati (2015) have also conducted research related to AUN-QA. They tried to improve the learning outcomes based on the AUN-QA criteria. They said that the learning outcomes should include knowledge and understanding, intellectual skills, practical skills, and transferable skills that are in line with the stakeholders' needs.

Based on the previous research explained above the writers tried to link the needs of stakeholders and reformulate the learning outcome of ELT study program, English Department, Faculty of Languages and Arts Universitas Negeri Padang based on the needs and standards of the ASEAN University Network Quality Assurance (AUN-QA).

\section{METHOD}

This need analysis was conducted in English department Faculty of Languages and Arts Universitas Negeri Padang. The subjects of the research were the stakeholders who have important roles in curriculum development. Those were alumni, lecturers, students, and users. Those subjects were given the questionnaires which included open-ended questions. The data from the questionnaire were analyzed by conducting descriptive statistics. The data, including data from rating scale items were coded and analyzed to find out the needs of every stakeholder.

\section{FINDINGS AND DISCUSSION}

The results of the need analysis are explained in the form of development steps that have been done for the development of curriculum of ELT Study Program. At this stage of the first year of research, curriculum development is conducted for three development steps, namely needs analysis, development design, curriculum model development, while the implementation and evaluation stage will be done after all draft models are developed. In this paper, the writer explained the result of the need analysis. After that, the results of the needs are presented in the revised learning outcomes in curriculum of ELT Study Program.

\section{A. Findings}

\section{The Needs of Stakeholders}

The data of the needs were found from five components. Those are the needs of students according to students, the needs of students according to lecturers, the needs of students according to Alumni who work on the education field, the needs of students according to alumni who work on non education field, and suggestion from the stakeholders. The results can be seen from the table 1 below.

Table 1. The Needs According to Stakeholders

\begin{tabular}{|c|c|c|c|}
\hline No & Stakeholders & The Aspects & The Needs \\
\hline \multirow[t]{3}{*}{1} & \multirow[t]{3}{*}{ Students } & Profesional Aspect & $\begin{array}{ll}- & \text { Listening skills } \\
- & \text { Knowledge of English phenomena in relation to social } \\
- & \text { Knowledge of Linguistics }\end{array}$ \\
\hline & & Pedagogical Aspect & $\begin{array}{ll}- & \text { Knowledge of language teaching Instruction } \\
\text { - } & \text { Knowledge of ICT }\end{array}$ \\
\hline & & Learning Process Aspect & $\begin{array}{ll}\text { - } & \text { Group discussion } \\
\text { - } & \text { Learning English by using media }\end{array}$ \\
\hline \multirow[t]{2}{*}{2} & \multirow[t]{2}{*}{ Lecturers } & Professional Aspect & $\begin{array}{ll}- & \text { The knowledge of Issues in English Language Teaching (ELT) } \\
\text { - } & \text { Knowledge of ICT in ELT }\end{array}$ \\
\hline & & Pedagogical Aspect & - $\quad$ Knowledge of Innovative learning \\
\hline \multirow[t]{4}{*}{3} & \multirow[t]{4}{*}{$\begin{array}{l}\text { Alumni } \\
\text { (Education Field) }\end{array}$} & Professional Aspect & $\begin{array}{ll}- & \text { Teaching English across discipline } \\
- & \text { Long life learning }\end{array}$ \\
\hline & & Social Aspect & - $\quad$ Knowledge how to socialize \\
\hline & & Personal Aspect & - $\quad$ Attitude \\
\hline & & Professional Aspect & - $\quad$ Knowledge of ICT in ELT \\
\hline 4 & $\begin{array}{l}\text { Alumni (Non- } \\
\text { Education Field) }\end{array}$ & Soft skill & $\begin{array}{ll}- & \text { Management } \\
- & \text { Entrepreneurship }\end{array}$ \\
\hline
\end{tabular}


Based on the table above, it can be seen that there are some point that should be considered in revised the learning outcomes. There are some of the points presented in the table that has been put in the previous curriculum of ELT study program. However, some suggestion from stakeholders in the aspect of competence and soft skills would be formulated and put them into revised learning outcomes. Those suggestions in the scope of soft skills include the students have to have the knowledge of how to communicate with others in a good way, being confidence, being discipline, and having the soul of leadership. In competence scope, students have to have the knowledge in ICT, statistics, media, entrepreneurship, management, and they have to have the knowledge of how to teach English for Specific Purposes (ESP). Furthermore, the writers also think about the ten skills for the future workforce. Those are:

a. Sense-making: ability to determine the deeper meaning of significance of what is being expressed

b. Sosial Intelligence: Ability to connect to others in a deep and direct way, to sense and stimulate reactions and desired interactions

c. Novel and Adaptive Thinking: Proficiency at thinking and coming up with solutions and responses beyond that which is role or rule-based

d. Cross-Cultural Competency: Ability to eperate in different cultural settings

e. Computational Thinking: Ability to translate vast amounts of data into abstract concepts and to understand data-based reasoning

f. New-Media Literacy: Ability to critically assess and develop content that uses new media forms, and to laverage these media for persuasive communication

g. Transdisciplinarity: Literacy in and ability to understand concepts across multiple disciplines

h. Design Mindset: ability to represent and develop tasks and work processes for desired outcomes.

i. Cognitive load development: ability to descriminate and filter information for importance, and to understand how to maximize cognitive functioning using a variety of tools and techique.

j. Virtual Collaboration: Ability to work productively; drive engagement, and demonstrate presence as a member of a virtual team

2. The Formulation of Learning Outcomes Based on the Standards of ASEAN University Network Quality Assurance (AUN$Q A)$

Based on the needs of stakeholders, the writers revised the learning outcomes based on the standard of AUN-QA. The learning outcomes can be seen from the points below.

a. Subject Specific Knowledge

1) Intellectual Knowledge

a) Demonstrate the knowledge of English lexicogrammar features by having learners engage in a range of communicative tasks and activities.

b) Demonstrate the knowledge of English language skills in listening, speaking, reading and writing by having learners engage in a range of communicative tasks and activities.

c) Analyze English linguistic and cultural features for the purposes of Teaching English to Speakers of Other Languages (TESOL) in a wide range of contexts.

d) Critically analyze teaching programs, curriculum, strategies, methods and techniques, learning materials and media, and assessment and evaluation in TESOL.

e) Explain the underlying approaches (paradigms) in conducting quantitative and qualitative research in English language education

2) Practical Skills

a) Expand the learner's use of lexicogrammatically correct and situationally appropriate language in speaking and writing for effective communication in a variety of interpersonal and academic situations.

b) Demonstrate to ability to listen, speak, read and write in English with advanced accuracy and fluency for a variety of purposes.

c) Apply the most suitable teaching strategies, methods and techniques, learning material, and assessment in TESOL considering the developmental characteristics and individual differences of the students.

d) Perform advanced study activities such as gathering and organizing informationn from different sources, wrting academic papers and following the range of citation convention

e) Design the Instructional Programs for Teaching English to Speakers of Other Languages (TESOL) considering the developmental characteristics and individual differences of the students

f) Use English appropriately in the non-English teaching situations such in tanslation and interpretation, public relation, and English for Specific Purposes. 
g) Communicate fluently and acurately in an Asian language both in oral and written modes.

b. Expected Learning Outcomes (Generic and Transferable Skills)

1) Communicate language teaching, applied linguistic and educational work in a variety of written formats;

2) Communicate responses to applied linguistic and educational work orally, in discussion and in formal presentations;

3) Use information technology appropriately when presenting work and in teaching;

4) Demonstrate interpersonal and collaborative skills whilst working with others in the investigation of problems, and in the presentation of arguments and evidence.

5) Interpret ethical and legal issues involved in English Language Education research.

6) Share ideas and solution offers for the problems with quantitative and qualitative data support.

Based on the points above, there two divisions that should be existed in curriculum particularly in learning outcomes based on AUN-QA standards. Those are subject specific knowledge and Expected Learning Outcomes (Generic and Transferable Skills). However, there are some points that had been revised from expert in Universitas Gadjah Mada (UGM). Those points that should be revised according to her are:

1. It would be better if the points in learning outcomes are cut off because there are too many points that are overlap.

2. There are overlapping points between learning outcomes in intellectual knowledge part and learning outcomes in practical skills part.

3. Use operational verbs in each learning outcomes so that those are easily measured.

Based on the suggestions above, the writers had been revised the learning outcomes. Those learning out comes can be seen from the points below.

1. The Revised Graduate Profile

a. Professional English teacher with strong fundamental knowledge and transferable skills.

b. Novice researcher with the ability to conduct research in English Language Teaching (ELT)

c. Competent entrepreneur in the field of English, journalism, or public relation.

2. Revised Program Learning Outcomes (Subject Specific Knowledge and Skills)

a. Demonstrate the ability to listen, speak, read and write in English with advance accuracy and fluency for a variety of purposes.

b. Analyze texts of different genres by making use of lexicogrammatical knowledge

c. Analyze English linguistic and cultural features for the purposes of TESOL in a wide range of contexts.

d. Apply the most suitable teaching strategies, methods and techniques, learning material, and assessment in TESOL considering the developmental characteristics and invidual differences of the students

e. Conduct quantative and qualitative research in English language education

f. Use English appropriately in non-English teaching situations such as in translation and interpretation, public relations, and English for Specific Purposes.

g. Communicate in an Asian language both in oral and written modes

3. Revised Program Learning Outcomes (Generic and Transferable Skills)

a. Communicate language teaching, applied linguistic and educational work both in a variety of written formats and spoken modes

b. Use information technology appropriately when presenting work and in teaching

c. Demonstrate interpersonal and collaborative skills whilst working with others in the investigation of problems, and in the presentation of arguments and evidence.

d. Employ critical and analytical thinking skills in solving problems in language teaching and other related fields.

Those points above are the revision of learning outcomes and those can be measured. The points can also be seen from the table 2 below. 1 
Table 2. Program Learning Outcomes

\begin{tabular}{|c|c|c|c|}
\hline & Expected Learning Outcomes & Teaching and Learning Methods & Assessment Methods \\
\hline & \multicolumn{3}{|c|}{ SUBJECT SPECIFIC KNOWLEDGE } \\
\hline & \multicolumn{3}{|c|}{ Intellectual Knowledge } \\
\hline No & $\begin{array}{l}\text { On completion of the program } \\
\text { the successful students will be } \\
\text { able to: }\end{array}$ & $\begin{array}{l}\text { Students gain knowledge and } \\
\text { understanding through: }\end{array}$ & $\begin{array}{l}\text { Students' knowledge and } \\
\text { understanding is assessed by: }\end{array}$ \\
\hline 1 & $\begin{array}{l}\text { Demonstrate the knowledge of } \\
\text { English lexicogrammar features } \\
\text { by having learners engage in a } \\
\text { range of communicative tasks } \\
\text { and activities. }\end{array}$ & $\begin{array}{ll}- & \text { Lectures } \\
\text { - } & \text { tutorials } \\
\text { - } & \text { Lexicogrammar analysis tasks } \\
- & \text { Communicative tasks } \\
\text { - } & \text { Self-directed reading of textbooks, } \\
& \text { textbook extracts and journal articles }\end{array}$ & $\begin{array}{ll}\text { - } & \text { Formal oral and written } \\
& \text { examinations } \\
\text { - } & \text { Lexicagrammar analysis reports } \\
\text { - } & \text { Oral presentation } \\
\text { - } & \text { Material evaluation reports }\end{array}$ \\
\hline 2 & $\begin{array}{l}\text { Demonstrate the knowledge of } \\
\text { English language skills in } \\
\text { listening, speaking, reading and } \\
\text { writing by having learners } \\
\text { engage in a range of } \\
\text { communicative tasks and } \\
\text { activities. }\end{array}$ & $\begin{array}{ll}- & \text { Lectures } \\
\text { - } & \text { Tutorials } \\
\text { - } & \text { Text and context analysis tasks } \\
\text { - } & \text { Communicative tasks } \\
\text { - } & \text { Self-directed reading of textbooks, } \\
& \text { textbook extracts and journal articles }\end{array}$ & $\begin{array}{ll}\text { - } & \text { Formal oral and written } \\
& \text { examinations } \\
\text { - } & \text { Lexicagrammar analysis reports } \\
\text { - } & \text { Oral presentation } \\
\text { - } & \text { Material evaluation reports }\end{array}$ \\
\hline 3 & $\begin{array}{l}\text { Analyze English linguistic and } \\
\text { cultural features for the } \\
\text { purposes of Teaching English to } \\
\text { Speakers of Other Languages } \\
\text { (TESOL) in a wide range of } \\
\text { contexts. }\end{array}$ & $\begin{array}{ll}- & \text { Lectures } \\
\text { - } & \text { Tutorials } \\
\text { - } & \text { Interactive discussions and seminars } \\
\text { - } & \text { Linguistic analysis tasks } \\
\text { - } & \text { Cultural feature analysis tasks } \\
\text { - } & \text { Library research tasks } \\
\text { - } & \text { Self-directed reading of textbooks, } \\
& \text { textbook extracts and journal articles }\end{array}$ & $\begin{array}{ll}\text { - } & \text { Formal oral and written } \\
& \text { examinations } \\
\text { - } & \text { Linguistic and cultural analysis } \\
& \text { reports } \\
\text { - } & \text { Oral presentation } \\
\text { - } & \text { Material evaluation reports } \\
\text { - } & \text { Learner profile task }\end{array}$ \\
\hline 4 & $\begin{array}{l}\text { Critically analyze teaching } \\
\text { programs, curriculum, } \\
\text { strategies, methods and } \\
\text { techniques, learning materials } \\
\text { and media, and assessment and } \\
\text { evaluation in TESOL. }\end{array}$ & $\begin{array}{ll} & \text { Lectures } \\
\text { - } & \text { Tutorials } \\
\text { - } & \text { Interactive discussions and seminars } \\
\text { - } & \text { Needs analysis tasks } \\
\text { - } & \text { Self-directed reading of textbooks, } \\
& \text { textbook extracts and journal articles }\end{array}$ & $\begin{array}{ll}\text { - } & \text { Formal oral and written } \\
& \text { examinations } \\
\text { - } & \text { essays } \\
\text { - } & \text { Lexicagrammar analysis reports } \\
\text { - } & \text { Oral presentation } \\
\text { - } & \text { Needs analysis reports } \\
\text { - } & \text { Material evaluation reports } \\
\end{array}$ \\
\hline 5 & $\begin{array}{l}\text { Explain the underlying } \\
\text { approaches (paradigms) in } \\
\text { conducting quantitative and } \\
\text { qualitative research in English } \\
\text { language education }\end{array}$ & $\begin{array}{ll}- & \text { Lectures } \\
\text { - } & \text { Tutorials } \\
\text { - } & \text { Interactive seminars and discussions } \\
\text { - } & \text { Self-directed reading of textbooks, } \\
& \text { textbook extracts and journal articles }\end{array}$ & $\begin{array}{ll}\text { - } & \text { Formal oral and written } \\
& \text { examinations } \\
\text { - } & \text { Oral presentation } \\
\text { - } & \text { Critical review writing } \\
\text { - } & \text { Proposal writing } \\
\text { - } & \text { Material evaluation reports } \\
\end{array}$ \\
\hline \multicolumn{4}{|c|}{ Practical Skills } \\
\hline 6 & $\begin{array}{l}\text { Expand the learner's use of } \\
\text { lexicogrammatically correct and } \\
\text { situationally appropriate } \\
\text { language in speaking and } \\
\text { writing for effective } \\
\text { communication in a variety of } \\
\text { interpersonal and academic } \\
\text { situations. }\end{array}$ & \multirow[t]{2}{*}{$\begin{array}{ll}\text { - } & \text { Lectures } \\
\text { - } & \text { tutorials } \\
\text { - } & \text { Interactive Seminars and discussions } \\
\text { - } & \text { Communicative tasks } \\
\text { - } & \text { Self-directed reading of textbooks, } \\
& \text { textbook extracts and journal articles }\end{array}$} & \multirow[t]{2}{*}{$\begin{array}{ll}\text { - } & \text { Formal oral and written } \\
& \text { examinations } \\
\text { - } & \text { Essay (academic) writing } \\
\text { - } & \text { Oral presentation } \\
\text { - } & \text { Material evaluation reports }\end{array}$} \\
\hline 7 & $\begin{array}{l}\text { Demonstrate the ability to listen, } \\
\text { speak, read and write in English } \\
\text { with advanced accuracy and } \\
\text { fluency for a variety of } \\
\text { purposes. }\end{array}$ & & \\
\hline
\end{tabular}


Table 2. Cont

\begin{tabular}{|c|c|c|c|}
\hline 8 & $\begin{array}{l}\text { Apply the most suitable teaching } \\
\text { strategies, methods and } \\
\text { techniques, learning material, and } \\
\text { assessment in TESOL considering } \\
\text { the developmental characteristics } \\
\text { and individual differences of the } \\
\text { students. }\end{array}$ & $\begin{array}{ll}\text { - } & \text { Interactive Seminars and discussions } \\
\text { - } & \text { Library research tasks } \\
\text { - } & \text { Observation of model and peer-taught } \\
& \text { lessons } \\
\text { - } & \text { Material and media development tasks } \\
\text { - } & \text { Self-directed reading of textbooks, } \\
& \text { textbook extracts and journal articles }\end{array}$ & $\begin{array}{ll} & \text { Peerteaching } \\
\text { - } & \text { Teaching practice } \\
\text { - } & \text { Oral presentation } \\
\text { - } & \text { Material evaluation reports } \\
\text { - } & \text { Reports on observed model } \\
& \text { lessons }\end{array}$ \\
\hline 9 & $\begin{array}{l}\text { Perform advanced study activities } \\
\text { such as gathering and organizing } \\
\text { informationn from different } \\
\text { sources, wrting academic papers } \\
\text { and following the range of citation } \\
\text { convention }\end{array}$ & $\begin{array}{ll}\text { - } & \text { Lectures } \\
\text { - } & \text { Tutorials } \\
\text { - } & \text { Interactive seminars and discussions } \\
\text { - } & \text { Self-directed reading of textbooks, } \\
& \text { textbook extracts and journal articles }\end{array}$ & $\begin{array}{ll}\text { - } & \text { Formal oral and written } \\
& \text { examinations } \\
\text { - } & \text { Oral presentation } \\
\text { - } & \text { Critical review writing } \\
\text { - } & \text { Proposal writing } \\
\text { - } & \text { Material evaluation reports } \\
\end{array}$ \\
\hline 10 & $\begin{array}{l}\text { Design the Instructional Programs } \\
\text { for Teaching English to Speakers } \\
\text { of Other Languages (TESOL) } \\
\text { considering the developmental } \\
\text { characteristics and individual } \\
\text { differences of the students }\end{array}$ & $\begin{array}{ll}\text { - } & \text { Interactive Seminars and discussions } \\
\text { - } & \text { Library research tasks } \\
\text { - } & \text { Observation of model and peer-taught } \\
& \text { lessons } \\
\text { - } & \text { Material and media development tasks } \\
\text { - } & \text { Self-directed reading of textbooks, } \\
& \text { textbook extracts and journal articles }\end{array}$ & $\begin{array}{ll}\text { - } & \text { Oral presentation } \\
\text { - } & \text { Material evaluation reports } \\
\text { - } & \text { Reports on observed model } \\
\text { lessons }\end{array}$ \\
\hline 11 & $\begin{array}{l}\text { Use English appropriately in the } \\
\text { non-English teaching situations } \\
\text { such in tanslation and } \\
\text { interpretation, public relation, and } \\
\text { English for Specific Purposes. }\end{array}$ & $\begin{array}{ll}\text { - } & \text { Lectures } \\
\text { - } & \text { Tutorials } \\
\text { - } & \text { Roleplays and simulations } \\
\text { - } & \text { Interactive Seminars and discussions } \\
\text { - } & \text { Communicative tasks }\end{array}$ & $\begin{array}{ll}\text { - } & \text { Formal oral and written } \\
& \text { examinations } \\
\text { - } & \text { Essay (academic) writing } \\
\text { - } & \text { Oral presentation } \\
\text { - } & \text { Material evaluation reports }\end{array}$ \\
\hline 12 & $\begin{array}{l}\text { Communicate fluently and } \\
\text { acurately in an Asian language } \\
\text { both in oral and written modes. }\end{array}$ & $\begin{array}{l}\text { - Self-directed reading of textbooks, } \\
\text { textbook extracts and journal articles }\end{array}$ & - Problem solving asessment \\
\hline & \multicolumn{3}{|c|}{ GENERIC AND TRANSFERABLE SKILLS } \\
\hline 13 & $\begin{array}{l}\text { Communicate language teaching, } \\
\text { applied linguistic and educational } \\
\text { work in a variety of written } \\
\text { formats. }\end{array}$ & \multirow{3}{*}{$\begin{array}{ll}\text { - } & \text { Lectures } \\
\text { - } & \text { Tutorials } \\
\text { - } & \text { Roleplays and simulations } \\
\text { - } & \text { Interactive Seminars and discussions } \\
\text { - } & \text { Communicative tasks } \\
\text { - } & \text { Self-directed reading of textbooks, } \\
& \text { textbook extracts and journal articles }\end{array}$} & \multirow{3}{*}{$\begin{array}{ll}\text { - } & \text { Formal oral and written } \\
& \text { examinations } \\
\text { - } & \text { Essay (academic) writing } \\
\text { - } & \text { Oral presentation } \\
\text { - } & \text { Material evaluation reports } \\
\text { - } & \text { Problem solving asessment }\end{array}$} \\
\hline 14 & $\begin{array}{l}\text { Communicate responses to } \\
\text { applied linguistic and educational } \\
\text { work orally, in discussion and in } \\
\text { formal presentations. }\end{array}$ & & \\
\hline 15 & $\begin{array}{l}\text { Use information technology } \\
\text { appropriately when } \\
\text { work and in teaching. }\end{array}$ & & \\
\hline 16 & $\begin{array}{l}\text { Demonstrate interpersonal and } \\
\text { collaborative skills whilst working } \\
\text { with others in the investigation of } \\
\text { problems, and in the presentation } \\
\text { of arguments and evidence. }\end{array}$ & $\begin{array}{ll}- & \text { Lectures } \\
\text { - } & \text { Tutorials } \\
\text { - } & \text { Interactive seminars and discussions } \\
\text { - } & \text { Self-directed reading of textbooks, } \\
& \text { textbook extracts and journal articles }\end{array}$ & $\begin{array}{ll}\text { - } & \text { Formal oral and written } \\
& \text { examinations } \\
\text { - } & \text { Oral presentation } \\
\text { - } & \text { Critical review writing } \\
\text { - } & \text { Proposal writing } \\
\text { - } & \text { Material evaluation reports } \\
\end{array}$ \\
\hline 17 & $\begin{array}{l}\text { Interpret ethical and legal issues } \\
\text { involved in English Language } \\
\text { Education research. }\end{array}$ & $\begin{array}{ll}\text { - } & \text { Interactive Seminars and discussions } \\
\text { - } & \text { Library research tasks } \\
\text { - } & \text { Observation of model and peer-taught } \\
& \text { lessons } \\
\text { - } & \text { Material and media development tasks } \\
\text { - } & \text { Self-directed reading of textbooks, } \\
& \text { textbook extracts and journal articles }\end{array}$ & $\begin{array}{ll}\text { - } & \text { Oral presentation } \\
\text { - } & \text { Material evaluation reports } \\
\text { - } & \text { Reports on observed model } \\
\text { lessons }\end{array}$ \\
\hline
\end{tabular}




\section{B. Discussions}

Curriculum should be based on the philosophy of education, sociology, psychology, and global life. It means that curriculum cannot be separated from many other disciplines such as psychology, philosophy, sociology and ideology. As Tinsae (2019) says that it is the combination between the philosophical perspectives, the students' and teachers' experience, instructional methodologies, and expected and unexpected outputs acquired within a learning institution. So, if the foundations are ignored or not considered in developing the curriculum, the learning outcomes cannot be achieved and of course the curriculum cannot work well.

Besides, the curriculum should be work dynamically and appropriately with the demands of current education issues. So, the process of evaluation should be done regularly to meet the standard what needs of national education objectives. It is advocated by Hussain, Dogar, Azeem, and Shakoor (2011) who says that the process of curriculum development should be evaluated because the evaluation has an important role to channelize and keep on the track toward what young generation desire to be achieved and keep the system update in national objectives. As one of the ASEAN Community, the curriculum needs to be developed continuously to meet the challenges of the world in the scope of ASEAN.

Curriculum has a function to achieve the education goal and it should be in line with the vision of each institution. In ELT study program of FBS, the curriculum has to be developed to achieve the vision of the study program to become one of the best study programs in ASEAN in preparing English teachers or instructors who have better in information, technology, and communication. To realize the vision, the writers as the curriculum developers in this ELT study program reformulated the learning outcomes of the curriculum itself. Hartel and Foegeding (2004) says that learning outcomes can be defined as a very specific statement that describes exactly what a student will be able to do in some measurable way. It means that the components in curriculum particularly the learning outcomes have to be measured and of course those should be based on the needs of stakeholders (students, lecturers, and alumni) and should be aligned with the standards of ASEAN University Network Quality Assurance (AUN-QA).

In this article, the writers had analyzed the needs of stakeholders. The results showed that there are some opinion and suggestions from them according to the aspects of knowledge and skills to be acquired in ELT curriculum. Some of the learning outcomes had been aligned with the demands of stakeholders and it was found all of stakeholders agreed that the knowledge of ICT is important for students. However, those learning outcomes should be revised based on the suggestion from the expert mentioned above. The expert said that the learning outcomes should be measured by using the operational verbs in each learning outcomes so that those are easily measured. A good learning outcome will have a verb that identifies what action the student should be able to perform (Hartel and Foegeding, 2004). In line with Hayati, Utami, Suharmanto, and Hidayati (2015) who also conducted the research related to the learning outcomes based on AUN-QA standard. They say that ICT knowledge and skills should be existed in learning outcomes. They also add that it needs to be improved, reformulated, and elaborated the learning outcomes that range from higher thinking skills, measurability and observability, based on the stakeholders' needs and demands, ESP oriented outcomes, language skills and component related outcomes, ICT knowledge and skills in ELT, to attitude-based outcomes.

\section{CONCLUSION AND SUGGESTION}

The research development of curriculum model of the English Education Study program uses the ADDIE Development model, with development steps (1) Analysis of stakeholders' needs (2) Design of curriculum based on the needs (3) Develop the curriculum (4) Implement the curriculum, and (5) Evaluate the curriculum. This first year research is only up to the stage of analyzing the needs, designing the learning outcomes in ELT study program, and developing the learning outcomes. Based on the results of this research, there are some conclusions presented. First, there have been the needs of stakeholders toward the curriculum development based on AUN QA standards and the second is it has been made the design and development of drafted curriculum of ELT Study Program based on AUN QA standards.

In relation to the above conclusions, the writers give some suggestions related to the curriculum development of ELT study program. First, the lecturers need to be equipped with the knowledge of developing a course profile based on the AUN QA criteria before developing their develop their course profiles and the second is the demands for the student knowledge and competence will be fulfilled if all stakeholders are involved in the implementation of the curriculum that has been developed.

\section{References}

Hartel, R, W \& Foegeding, E, A. 2004. Learning: Objectives, Competencies, or Outcomes? Journal of Food Science Education, 3: $69-70$

Hayati, N, Utami, W, Suharmanto, Hidayati, M. (2015). Developing AUN-QA-Based Learning Outcomes of Enhlish Langauge Teaching Study Programs. Makalah yang dipresentasikan di TEFLIN Conference, Bali

Hussain, A, Dogar, A, H, Azeem, M, Shakoor, A. (2011). Evaluation of Curriculum Development Process. International Journal of Humanities and Social Science, 1 (14): 264-271 
Suharmanto, Maria, H, \& Evynurul, L, Z. (2010). Improving the Teaching and Learning Quality by Developin AUN-QA-Based Course Outlines. Bahasa dan Seni, 41 (2): 248-255.

Tinsae, E, W. 2016. A critical Review and Analysis of the Definitions of Curriculum and the Relationship between Curriculum and Instruction. International Journal of Research in Engineering and Social Sciences, 6 (4): 8-12 